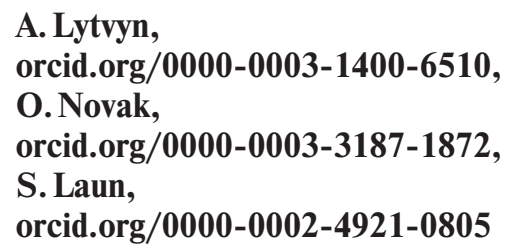

Hryhorii Skovoroda University in Pereiaslav, Pereiaslav, Ukraine, e-mail: novakolyia@gmail.com

\title{
FORMATION OF RESEARCH COMPETENCE AT THE UNIVERSITY: ECONOMIC AND MANAGERIAL ASPECTS
}

Purpose. To study the features of the influence of economic factors and management on the formation of research competence at the university as a social institution, as well as their reverse effect. Namely, the influence of university graduates with research competence on the socio-economic development of the state.

Methodology. The authors used the "qualitative meta-synthesis" approach as the main research method. The authors carried out metasynthetic work, i.e., studied the currently available literature on the stated problem of the study, considered existing practices, as well as their results. The thematic coding strategy based on the selection and use of pragmatic and metadiscourse markers was used to synthesize the obtained research results.

Findings. The authors found that the attitude to and the ways of forming research competence are determined by the State policy in the field of education. In economically developed countries, research competence is one of the key markers that reveal the effectiveness of the relationship between the state and the university as a social institution. The state stimulates the development of university laboratories and research centers in exchange for professional researchers who ensure the socio-economic development of society.

Originality. The authors identified two key markers for the formation of research competence in university education. The first is targeted state education policy. The second is the economic and managerial autonomy of universities, which allows them to turn university laboratories into research centers that can effectively solve problems of state, regional, and global scale.

Practical value. The results obtained are necessary to clarify the process of reforming the Ukrainian education system. They adapt the world experience to Ukrainian reality and establish key markers for the development of economic and managerial relations between the state and the university as a social institution.

Keywords: research competency, economics, management, university education, state

Introduction. The object of the study is the formation of research competence at the university as a social institution. The subject of the study is the influence of economic factors and management on the development of the research competence in university students, as well as the study of the results of the activities of university graduates demonstrating research competence on the socio-economic development of the state.

The relevance of the topic is ensured by two reasons. First, in the "Education Sector Survey in Ukraine", commissioned by the World Bank in 2019, the authors note the following negative trend. The education sector in Ukraine works on quantity rather than on quality. For example, the proportion of people aged 25 years and older with higher education reached about 40 percent, which exceeds the average for economically developed countries, members of the OECD [1]. However, it was revealed that [1]:

a) cognitive skills of students of Ukrainian higher educational institutions correspond to the level of cognitive skills of graduates of higher schools in economically developed countries;

b) as of 2013, 47 percent of Ukrainian university graduates were unemployed, and 40 percent were in low-level positions that did not require university education;

c) forty percent of employers reported that the skills of university graduates did not match the acquired specialties, which damaged their business goals.

The second reason is the low ratings of Ukrainian universities in The Times Higher Education World University Rankings 2020. The rating reveals the quality and prospects of the research conducted in university laboratories and research centers. The data is provided by the Elsevier publishing house, which owns the Scopus scientometric database. In 2020, six Ukrainian universities fell into this ranking. However, the best of them, Lviv Polytechnic National University (Lviv), ranks 801 out of 1000 place, i. e., is the only Ukrainian

(C) Lytvyn A., Novak O., Laun S., 2020 university that is among the top 1000 research universities in the world [2].

Results. Over the past decades, the University as a social institution and its requirements have changed significantly. According to opinion polls among students, the demand for "university spirit" and "university culture" has decreased. The desire to gain real competences capable of ensuring career growth after receiving a university education topped the list [3].

The European Qualifications Framework (EQF) clearly defines the competencies that university graduates must possess. These are four core competencies [4]:

- cognitive;

- functional (skills and know-how);

- personal;

- ethical.

The European Qualifications Framework (EQF), which operates in 38 European countries, covers qualifications at all levels and in all subsystems of education and training. It is based on an eight-level taxonomy: from a low (basic) level to the most developed eighth level. Each level determines the necessary minimum of knowledge, skills, personal and professional competencies [4].

At the last three levels, which put forward the requirements for higher education, research skill is constantly mentioned. At the eighth, highest level, this skill is formulated as "Research, develop, implement and adapt projects leading to new knowledge and new solutions" [4]. In fact, this is the main skill that is formed in the university environment, especially when studying for a Master's and doctoral degree.

SAGE publishes the journal Research Ethics, which formulates and constantly refines the criteria for key competencies relevant to modern education and professions. Argumentation is based on ethical standards. The study by J. MooneySomers and A. Olsen formulated the criteria for "research competence". According to the authors, the criteria for research competence are determined by the ethics of scientific research that has developed in the history of science over the 
past centuries. Using ethics as the basis of research competence makes its essence unified and universal in the modern world, and research competence itself is a necessary skill for higher education [5].

Thus, despite the fact that research competence is not listed in the European Qualifications Framework (EQF), it is formulated and reasoned as a competence and professional skill. Even within the European Union, many universities continue to regard it as the highest level of university education and professional activity.

Over the past 15 years, several concepts for the formation of research competence in higher education have been developed. The development of research competence occurs through the introduction of research-oriented training, the end result of which is the consolidation of research competence as a skill. Among the concepts, let us single out, e.g., the RMRC-K model [6], integrated models like the 4MAT Teaching and Learning Model and the Kirkpatrick Four-Level Evaluation Model [7], and others.

Research competencies are divided into three groups: generic competencies, those associated with user research, and those related to doing research [8]. Each group of research competencies provides for the use of special methods of formation and consolidation as a skill, as well as the expected end results.

If we consider the formation of research competence in the European Union, the Bologna Convention signed by governments requires all European higher education institutions to adopt a three-stage system of degrees: Bachelor, Master, and Doctor. Each degree has a "cycle" of approximately 3 years. Training for each new degree provides for the excellence of research competence. If a Bachelor's degree provides for the formation of research competence, then graduate education involves the use of research competence as a skill $[4,9]$.

A study by S. Medynskii et al. revealed a discrepancy between the states and the institutions in terms of their approaches to the formation of research competence, as well as the relevance of research competence in the state education policy. S. Medynskii et al. studied the problem of professional training of American specialists in physical education and sports at universities in the United States of America and compared it with training in higher educational institutions of Ukraine. The study covered more than 60 universities in both countries. Differences were identified across a wide range of issues, including a different attitude to the formation of research competence [10]. The authors came to the conclusion that the main reason for the fundamental difference in the understanding of competencies and approaches to their formation are different educational traditions, as well as contextual, institutional, and national priorities.

The influence of educational traditions on the development of state education policy and university study programs is important [11]. This is a historical and cultural context that forms the national identity of younger generations. It is used as the basis of state education policy and is controlled by the state.

A variety of educational traditions makes obvious the problem of unification of university programs and, accordingly, approaches to the formation of research competence. In fact, unification is impossible and impractical. It can be sufficiently illustrated by the following example from the studies carried out under the Erasmus program at universities in the European Union. Writing and defending a scientific study are formal requirements for a Master's degree. However, for example, all medical students in the Netherlands are required to carry out a research project for at least 4-6 months (full time), while in other countries, a research project provides much less time, is optional or not necessary at all [8].

Marz R., Dekker F. W., et al. conclude that it is impossible to unify approaches to the formation of research competence. They believe that the diversity of approaches creates competi- tion between educational traditions and helps to improve the quality of the research competence formation [8].

Thus, we can draw the first conclusion of our study. The attitude and ways of forming research competence are determined, first of all, by the state policy in the field of education. Let us consider the features of the state influence on the university as a social institution and on its educational programs, primarily on the formation of research competence.

The connection between politicians and teachers, between the humanistic and pragmatic orientations in modern higher education, determines the socio-economic development of society [12]. Therefore, all modern economically developed countries consider educational policy as a priority, and the formation of research competence as one of the main tasks of university education. Financing education as well as managing education at the state level provides for the formation and development of research competence.

Timashova V. and Strohanova H. prove the decisive role of education policy on the development of universities and university research programs. We draw attention to the fact that the authors make a distinction between the politics of education and education policy [13]. They argue that it is the politics of education that has a determining influence on the state economy and university management by the state. As an example, the authors describe funding of the research on the development of Mars from the US state budget [13]. For a long time, the idea of flying to Mars was considered utopian in the world and in American society, in particular. However, with the help of the politics of education, the state established the research scope and direction, allocated grants, and attracted universities to perform it. Over the past decade, the situation has changed dramatically. While all over the world, the expediency of flying to Mars continues to cause skepticism, in American society, this idea has come close to practical implementation. Moreover, the main argument in favor of the expediency of the money spent is the need to study Mars and explore outer space in general.

The main criterion for World University Rankings (Elsevier) is the scale and quality of research conducted in university laboratories and centers. Universities that are in the top ten of this ranking have research laboratories and centers equipped with the latest technology. Research is funded by the state, as well as financed by private investment companies. The scale of this funding, as well as the relevance of research far exceeds the research capabilities of the institutes of the Academy of Sciences of Ukraine.

Consider the features of the relationship between the state education policy and the policies of a particular university, aimed at developing its research potential. It is exemplified by Massachusetts Institute of Technology, which today is the world's largest research structure. In 2020, in World University Rankings 2020, the university ranked fifth, and it ranked first among technical higher education institutions. During this period, the university enrolled 4530 undergraduate students, 2884 graduate students, 3896 students studying for doctoral degrees, and 165 - for Specialist degree. The educational process, as well as research work, was carried out by 1075 teachers. The university target fund amounted to $\$ 17.57$ billion. Up to $\$ 1$ billion was allocated from university funds for military research solely [14].

Massachusetts Institute of Technology includes more than a hundred research laboratories and centers, the activities of which are determined by public, private and university funding. Research is conducted in all modern advanced areas, from research in the space industry to the research in nanotechnology. Eighty-one members of the Massachusetts Institute of Technology community have become Nobel Prize winners. This is a record number among all existing educational and research organizations.

The above example reveals the key features of the interaction between the state and the university as a social institution. 
Firstly, the state considers the university not only and not so much as an educational institution, but also as a research center that is capable of fulfilling any task on the agenda of society. The state provides the university with the necessary financial resources and provides broad autonomy so that the university independently determines its development strategy. In particular, it:

a) determines the relevance of the curriculum and the demand in society for the specialties and skills of graduates;

b) selects the research topics and provides quality control of the research;

c) provides the research laboratories and centers with technical and information and communication facilities, and so on.

The effectiveness of the university research results and the possibility of their implementation in practice are important for the state. It considers the university as a partner in joint work on the socio-economic development of the society. Therefore, economic and managerial relations between the state and the university are based on partnerships and solving common problems.

Secondly, the state creates and controls the competitive space in the university environment. It is not just university funding, but investments into specific studies and research groups whose effectiveness has been proven in fair competition. Such an education policy encourages universities to develop research laboratories and centers, work with personnel and provide technical support for their work. It is not the state, but the university that determines promising areas of research and proves their importance for the socio-economic development of the society. The university examines the implementation of state policy in everyday life and identifies the most vulnerable places in which its help is necessary for the state. In solving many problems, the university acts as an intermediary between the state and the society, analyzing and synthesizing the existing connections and the quality of their development.

The state benefits from a free and autonomous university. A university subordinated to the directives of the Ministry of Education and constrained by managerial accountability is not able to reach the level of financial independence. In the relationship between the state and the university as a social institution, the state retains only the quality control over the educational and research services of the university. The university carries out ongoing work and strategic planning independently.

Thirdly, economic and managerial relations between the state and universities provide the end result. It is:

a) formation of students' research competence;

b) practical embodiment of university research and its economic effect;

c) growth of economic, technical, and scientific potential of the state, and so on;

d) contribution of the university to solving current problems of the legislative and executive branches, etc.

The Western model of cooperation between the state and the university has two stakeholders. The state is interested in the practical benefits of financing higher education. The University as a social institution is interested in, along with educational services, bringing the capabilities of research laboratories and centers to the new and meaningful level, i.e., there are certain economic and managerial relations between the state and the university.

Leading universities in the world use their research laboratories and centers to achieve two goals:

1. To attract applicants not only to obtain Master's and doctoral degrees, but also to start Bachelor courses.

2. To attract public and private funding for their research programs.

For example, G.Zhukova and T. Bulgakova disclosed the dual use of university observatories and planetariums [15]. University observatories and planetariums are research centers, the construction and maintenance of which cost universities dozens of millions of dollars. Universities also attract private investors as partners to perform certain obligations. As a rule, this is "made-to-order" research, as well as a guarantee of certain results and achievements. However, G. Zhukova and T. Bulgakova claim that these expensive objects quickly pay off. Observatories and planetariums are used by universities [15]:

a) to attract talented youth to the university after graduation

b) to form the research competence in Bachelor's, Master's and doctoral degree programs;

c) to obtain regional and national research grants;

d) to attract private investors with the aim of creating new research centers.

The construction and use of university observatories and planetariums is one of many examples of the development of public and private funding by universities. It does not only pays for itself in the near future, but also brings significant dividends to the university and the state. University graduates have research competence as a fixed skill that manifests itself in the socio-economic development of the state and the growth of state capital. By stimulating university research projects, the state receives:

a) effective solutions to the challenges faced by the government and society;

b) professional researchers who are able to act as a driving force in the socio-economic development of the society.

It should be noted that in Western society, many postgraduate programs that employ specialists from various fields require interns to provide evidence of research activities. For example, in Ireland, each registered practitioner must annually submit in writing an official, standards-based review of a specific aspect of their practice and research [8]. Thus, the state creates conditions in which the relevance of research competence is maintained throughout life.

An analysis made by the authors of international publications in leading scientific databases Springer, Cambridge Core, Web of Science, Elsevier, and others revealed the following pattern. The issue of research competence development has ceased to be relevant in economically developed countries. The activity of publications on this issue ended at the beginning of the $21^{\text {st }}$ century. Its logical conclusion was the formation and consolidation of the criteria of "scientific research", namely:

a) ethics of modern scientific research;

b) approaches and methods for the formation of research competence in higher education;

c) academic requirements for writing research articles, and others.

The discovered fact does not indicate a loss of interest in this problem on the part of researchers. It indicates a solution to this problem. In highly developed states, economic and managerial ties between the state and the university as a social institution strengthened, which led to the sustainable development of the latter. In highly developed countries, the problem of research competence does not exist, since the state education policy provides for the development of the university as an educational and research center.

The study by R. Khany, M. Aliakbari, S. Mohammadi reveals the features of the formation of a "research" style of writing articles in English. The authors prove the existence of wellestablished and fundamental components of the style when writing research papers. Neglecting of these components makes any study unscientific [16].

The research by J. Gough focuses on the development of the research competence of professional translators [17].

Thus, we can draw the second conclusion of our study. The formation of research competence is an important marker for the development of economic and managerial relations between the state and the university as a social institution. The relevance of this marker signals the imperfection of this interaction and the need to reform the state education policy. The decrease in the relevance of this marker indicates the achieve- 
ment of sustainable development. The state and the university as a social institution are developing mutually complementing each other.

We use the results of the study to consider the relationship between the state and the university in Ukraine.

Ukraine occupies one of the leading places in Europe in the expenditures of the state budget for education. However, as emphasized by J. Gresham and D. Ambasz, the use of these funds is so ineffective that the Ukrainian education system is still at the initial stages of the reform [1]. The reasons for the inefficient use of allocated funds are:

1. Lack of development strategies of the education policy. On the one hand, Ukraine has committed itself to the implementation of the Bologna Convention. On the other hand, state policy is aimed at returning to historical and cultural traditions, which have little relation to the traditions of European education.

2. Poor quality management of the educational process. The university, as a social institution, is not autonomous and self-sufficient. It is unable to determine its own development strategy, attract private investment, and invest its own funds in research and promotion of research projects.

3. In Ukraine, educational services and research are still separated. The existence of the Academy of Sciences of Ukraine, which specializes in research and, accordingly, is financed from the state budget, creates a problem for the development of university research projects and their financing.

The study by S. Kravchenko provides a large-scale analysis of modern definitions of research competence in the studies of reputable Ukrainian scientists. The author examined more than 30 definitions of research competence. Based on the analysis, Kravchenko proposed a generalized definition of "research competence" [18].

Kravchenko and other Ukrainian researchers [19] insist on the need to form a "professional researcher" at the university as a social institution and, accordingly, to add research competence to the Ukrainian qualification system.

The study by Kravchenko, as well as the authors analyzed in it, reveals the relevance of the issue of research competence development, as well as establishing sustainable economic and managerial relations between the state and universities in the Ukrainian scientific community. Note that the relevance of this issue is characteristic of all developing countries, and not just of Ukraine. Noteworthy is the difference in approaches to the study of this problem. If we compare, e.g., a study by R. Marz, et al. [8] with that by Kravchenko [18], then in the first case the emphasis is on researching the effectiveness of research competence formation techniques, and in the second case, on analyzing the definition of "research competence". Ukrainian scientists only go through the stage of theoretical understanding of the steps of reforming the Ukrainian education system in order to develop effective economic and managerial ties between the state and the university as a social institution. Research competence and its developmental features are proposed as a key marker of this reform.

The previously considered examples of effective communication between the state and universities, as well as the specifics of funding and research management, allow us to draw the following conclusions. First, such a relationship has not been established in Ukraine. Reforming the Ukrainian education system involves changing many aspects. The sequence of reform steps and their features are disclosed in the "Review of the education sector in Ukraine" [1]. However, unfortunately, in this sequence of reforms of Ukraine's higher education, there are no clear markers that allow us to judge the effectiveness of the reform. In the Western tradition, one of the key markers that allow judging the effective relationship between the state and the university is the quality of the research competence formation. The higher the research potential of the university as a social institution is, the more graduates have research competence, which ensures, inter alia, the socio-eco- nomic development of the state. A professional researcher is the driving force of the society towards new technologies and standards of everyday lifestyle.

Second, in Ukraine, despite the length of reforms in the field of education and science, a paradoxical situation continues to persist. On the one hand, Ukraine signed the Bologna Convention, thereby committing itself to reform the education system in accordance with the European educational traditions. First of all, this provides for the actual rather than formal autonomy of universities, which allows universities to carry out strategic planning of their own activities. However, on the other hand, in Ukraine, there is still a division between the Academy of Sciences, which specializes in research and develops research grants, and the university as a social institution, which is virtually deprived of access to large-scale government funding for research. This is especially evident in terms of the research activities of classical and technical universities. In the world practice, state research grants are the main source of income for universities that allow them to develop the research potential of their own laboratories and centers.

Third, the lack of actual autonomy precludes the effectiveness of economic and managerial ties between the state and the university. In Ukraine, the university is not a partner of the state. This is manifested, for example, in the possibilities of creating and operating university laboratories and centers. The university is considered by the state primarily as an institution providing educational services. Educational services are the main source of income for the university. In order to create and develop research laboratories and centers, the university must have at least its own development strategy. The development strategy determines the directions of research, attracting public and private funding, constructing academic buildings and purchasing technical equipment, attracting specialists, and others. This is a whole process in which a sequence of actions, performers, and expected results are established.

The main result of creating research laboratories and centers is the formation of research competence and equal partnership with the state on the path of socio-economic development of society. Both graduate and doctoral degree education provides for compulsory work in a research center under the guidance of an experienced mentor. Students become important actors in the research process. The absence of laboratories and centers, or a formal attitude to them, excludes the qualitative formation of research competence. Accordingly, the state does not receive specialists with the necessary professional skills from universities.

Exploring the features of reform in university education in Ukraine, Oleksiyenko A. noted its main drawback, i.e., the lack of systematic studies of university management practices and relations between universities and the State [20]. What it involves is the research on the economic and managerial development of individual universes. In fact, this is a study of the stages of development of an individual university, primarily to understand the mistakes and achievements on the way traveled. The combination of these studies, as well as their versatility, creates a research base for the formation of the university development strategy and its relations with the state. In the Western world, such research is a prerequisite for the ongoing activities of universities. They allow the governing bodies of the university to evaluate their efforts to develop the university, as well as adjust plans for the future.

Oleksiyenko explains the lack of such practice in Ukrainian universities by the traditions of the Soviet heritage, which did not provide for the experience of conducting research for internal use or for public reporting. This was especially the case with the studies providing criticism of the relationship between the State and the university [20].

Conclusions. The article examined the features of the influence of economic factors and management on the formation of research competence at the university as a social institution, as well as the reverse effect. Namely, the influence of 
university graduates demonstrating research competence on the socio-economic development of the state.

The authors found that:

1. Research competence is one of the key markers that reveal the effectiveness of the interaction between the state and the university as a social institution.

2. In highly developed countries, the relevance of this topic remained in the past. The state considers universities as partners on the way of socio-economic development of the society [21]. It not only guarantees the autonomy of universities, but also encourages universities to develop their research potential along with educational services [22].

3. In Ukraine, as well as in other states that are just developing, the problem of the formation of research competence is crucial and paramount [23]. The authors propose considering it as a key marker for the reform of the university as a social institution and Ukrainian higher education.

\section{References.}

1. Gresham, J., \& Ambasz, D. (2019). Ukraine - Resume Flagship Report (Vol. 2). Review of the Education Sector in Ukraine: Moving toward Effectiveness, Equity and Efficiency (RESUME3). Washington, D.C.: World Bank Group. Retrieved from http:// documents.worldbank.org/curated/en/884261568662566134/ Review-of-the-Education-Sector-in-Ukraine-Moving-toward-Effectiveness-Equity-and-Efficiency-RESUME3.

2. World University Rankings 2020 (2019). Times Higher Education. Retrieved from https://www.timeshighereducation. com/student/best-universities/best-universities-world.

3. Możgin, W. (2019). The Condition of a Modern University - Is There a Problem? Future Human Image, 11, 56-65. https://doi.org/10.29202/fhi/11/6.

4. European qualifications framework (EQF) (2020). Retrieved from https://www.bsu.by/upload/page/172163.pdf.

5. Mooney-Somers, J., \& Olsen, A. (2016). Ethical review and qualitative research competence: Guidance for reviewers and applicants. Research Ethics, 13(3-4), 128-138. https://doi. org/10.1177/1747016116677636.

6. Böttcher, F., \& Thiel, F. (2018). Evaluating research-oriented teaching: a new instrument to assess university students' research competences. Higher Education, 75, 91-110. https:// doi.org/10.1007/s10734-017-0128-y.

7. Lin, Y.-W., \& Bazaluk, O. (2020). Using Brain Science Theory to Analyze the Unity between Language Input and Output: Methodology Improvement Substantiation. Psycholinguistics, 27(1), 195-218. https://doi.org/10.31470/23091797-2020-27-1-195-218.

8. Marz, R., Dekker, F.W., Van Schravendijk, C., O’Flynn, S., \& Ross, M.T. (2013). Tuning research competences for Bologna three cycles in medicine: report of a MEDINE2 European consensus survey. Perspectives on Medical Education, (2), 181195. https://doi.org/10.1007/s40037-013-0066-z.

9. Rudenko, S., Bazaluk, O., Tsvykh, V., \& Kalmuk, I. (2019). The Role of Philosophical Disciplines in Educational Strategies for Specialist Training in the Field of Public Administration. Naukovyi Visnyk Natsionalnoho Hirnychoho Universytetu, (3), 158-163. https://doi.org/10.29202/nvngu/2019-3/22.

10. Medynskii, S., Shandruk, S., \& Sovgira, S. (2018). Prospective View of Professional Study of Specialists in Physical Education and Sports in Higher Educational Universities of Ukraine (Based on the American experience). Future Human Image, 10, 50-61. https://doi.org/10.29202/fhi/10/5.

11. Bazaluk, O. (2019). Plato's Traditions in Modern Educational Theories. Annals of the University of Craiova - Philosophy Series, 43(1/2019), 5-20.

12. Terepyshchyi, S., \& Khomenko, H. (2019). The Dialectics of Humanism and Pragmatism as a Basis for the Formation of Higher Education Strategy Development. Ukrainian Policymaker, 5, 98-107. https://doi.org/10.29202/up/5/11.

13. Timashova, V., \& Strohanova, H. (2020). The Politics of Education and Its Impact on the Human Exploration of Mars.
Philosophy and Cosmology, 24, 122-130. https://doi. org/10.29202/phil-cosm/24/12.

14. Enrollment statistics by year 2019-2020 (2020). Massachusetts Institute of Technology. Retrieved from https://registrar. mit.edu/statistics-reports/enrollment-statistics-year.

15. Zhukova, G., \& Bulgakova, T. (2019). University Planetariums and Observatories: The Critical Role of Higher Education in Future Studies. Philosophy and Cosmology, 23, 130138. https://doi.org/10.29202/phil-cosm/23/12.

16. Khany, R., Aliakbari, M., \& Mohammadi, S. (2019). A model of rhetorical markers competence in writing academic research articles: a qualitative meta-synthesis. Asian-Pacific Journal of Second and Foreign Language Education, 4(1). https://doi.org/10.1186/s40862-018-0064-0.

17. Gough, J. (2019). Developing translation-oriented research competence: what can we learn from professional translators?, The Interpreter and Translator Trainer, 13(3), 342-359. https://doi.org/10.1080/1750399X.2019.1656404.

18. Kravchenko, S. A. (2018). Generalization of the essence of the definition of «research competence». Young Scientist, 2(54), 265-268.

19. Novak, O., Levchenko, L., Levchenko, I., \& Kostenko, O. (2019). Features of master's degree programs in Ukraine: formation of administrative competencies. Naukovyi Visnyk Natsionalnoho Hirnychoho Universytetu, (3), 158-163. https://doi. org/10.29202/nvngu/2019-1/18.

20. Oleksiyenko, A. (2019). Why Is Governance Research Important for University Reforms in Ukraine? Ukrainian Policymaker, 4, 27-35. https://doi.org/10.29202/up/4/5.

21. Kathryn, C. Senie (2016). Implementing transfer and articulation: A case study of community colleges and state universities. Community College Journal of Research and Practice, 40(4), 269-284. https://doi.org/10.1080/10668926.2015.1038 667.

22. Burston, Mary A. (2019). The complexities of academic productivity: a case analysis of postdoctoral research productivity in Australian universities. Journal of Further and Higher Education. https://doi.org/10.1080/0309877X.2019.1612157. 23. Knyazyan, M., \& Mushynska, N. (2019). The formation of translators' research competence at the universities of ukraine. Journal of Teaching English for Specific and Academic Purposes. 7(1), 85-94. https://doi.org/10.22190/JTESAP1901085K.

\section{Формування дослідницької компетенції в університеті: економічний та управлінський аспекти}

\section{А. Ф. Литвин, О. М. Новак, С. Ю. Лаун}

Університет Григорія Сковороди в Переяславі, м. Переяслав, Україна, e-mail: novakolyia@gmail.com

Мета. Встановити особливості впливу економічних чинників та управління на формування дослідницької компетенції в університеті як соціальному інституті, а також їх зворотний вплив. А саме, вплив випускників університетів, які мають дослідницьку компетенцію, на соціально-економічний розвиток держави.

Методика. В якості головного методу дослідження автори використали підхід «якісного метасинтезу». Авторами була зроблена метасинтезна робота, а саме досліджена доступна література за заявленої проблеми дослідження, розглянуті існуючі практики, а також їх результати. Для синтезу отриманих результатів дослідження була застосована тематична стратегія кодування, що заснована на виділенні й застосуванні прагматичних і метадискурсних маркерів.

Результати. Автори встановили, що відношення та шляхи формування дослідницької компетенції визначаються державною політикою в галузі освіти. В економічно розвинених державах дослідницька компетенція є од- 
ним із ключових маркерів, що розкриває ефективність розвитку відносин між державою та університетом як соціальним інститутом. Держава стимулює розвиток університетських лабораторій і дослідницьких центрів, натомість отримуючи професіоналів-дослідників, які забезпечують соціально-економічний розвиток суспільства.

Наукова новизна. Автори встановили два ключових маркери формування дослідницької компетенції в університетах. Перший, цілеспрямована державна освітня політика. Другий, економічна та управлінська автономія університетів, що дозволяє їм перетворити університетські лабораторії в дослідницькі центри, здатні ефективно вирішувати завдання державного, регіонального та глобального масштабу.

Практична значимість. Отримані результати необхідні для уточнення процесу реформування української системи освіти. Вони адаптують світовий досвід до української реальності та встановлюють ключові маркери розвитку економічних і управлінських відносин між державою та університетом як соціальним інститутом.

Ключові слова: дослідницька компетенція, економіка, управління, університетська освіта, держава

\section{Формирование исследовательской компетенции в университете: экономический и управленческий аспекты}

\section{А. Ф. Литвин, О. М. Новак, С. Ю. Лаун}

Университет Григория Сковороды в Переяславе, г. Переяслав, Украина, e-mail: novakolyia@gmail.com

Цель. Установить особенности влияния экономических факторов и управления на формирование исследовательской компетенции в университете как социальном институте, а также их обратное влияние. А именно, влияние выпускников университетов, обладающих исследовательской компетенцией, на социально-экономическое развитие государства.

Методика. В качестве основного метода исследования авторы использовали подход «качественного мета- синтеза». Авторами была проведена метасинтезная работа, а именно исследована доступная в настоящее время литература по заявленной проблеме исследования, рассмотрены существующие практики, а также их результаты. Для синтеза полученных результатов исследования была применена тематическая стратегия кодирования, основанная на выделении и использовании прагматических и метадискурсных маркеров.

Результаты. Авторы установили, что отношение и пути формирования исследовательской компетенции определяются государственной политикой в сфере образования. В экономически развитых государствах исследовательская компетенция является одним из ключевых маркеров, который раскрывает эффективность развития отношений между государством и университетом как социальным институтом. Государство стимулирует развитие университетских лабораторий и исследовательских центров, взамен получая профессионалов-исследователей, которые обеспечивают социально-экономическое развитие общества.

Научная новизна. Авторы установили два ключевых маркера формирования исследовательской компетенции в университетах. Первый, целенаправленная государственная образовательная политика. Второй, экономическая и управленческая автономия университетов, которая позволяет им превратить университетские лаборатории в исследовательские центры, способные эффективно решать задачи государственного, регионального и глобального масштаба.

Практическая значимость. Полученные результаты необходимы для уточнения процесса реформирования украинской системы образования. Они адаптируют мировой опыт к украинской реальности и устанавливают ключевые маркеры развития экономических и управленческих отношений между государством и университетом как социальным институтом.

Ключевые слова: исследовательская компетенция, экономика, управление, университетское образование, государство

Recommended for publication by M.V. Bratko, Doctor of Pedagogical Sciences. The manuscript was submitted 19.12.19. 